\title{
Observational study of inflammatory arthritis treatment by etanercept originator switched to an etanercept biosimilar
}

\author{
Anna Felis-Giemza ${ }^{1}$, Kornelia Chmurzyńska ${ }^{1}$, Jolanta Nałęcz-Janik ${ }^{1}$, \\ Katarzyna Romanowska-Próchnicka², Katarzyna Świerkocka ${ }^{1}$, Mariusz Wudarski ${ }^{1}$, \\ Marzena Olesińska ${ }^{1}$ \\ ${ }^{1}$ Department of Systemic Connective Tissue Diseases, Biological Therapy Center, National Institute of Geriatrics, Rheumatology \\ and Rehabilitation, Warsaw, Poland \\ ${ }^{2}$ Department of General and Experimental Pathology with Centre for Preclinical Research and Technology (CEPT), Medical University \\ of Warsaw, Poland
}

\begin{abstract}
Objectives: The aim of the study was to assess the safety and efficacy of switching an etanercept originator to an etanercept biosimilar in rheumatoid arthritis, juvenile idiopathic arthritis, psoriatic arthritis, and ankylosing spondylitis patients.

Material and methods: In 162 patients etanercept originator treatment had been replaced with the biosimilar (Group 1), and in six patients the biosimilar was initiated as the first biological agent (Group 2). The efficacy and safety of the treatment were monitored at 3-6 months.

Results: In the majority of patients in Group $1(n=138)$ the etanercept biosimilar was well tolerated, whereas in 24 patients a switch back to the originator was required. The loss of efficacy was confirmed in nine patients using clinical scoring system, and nine patients reported subjective loss of efficacy; 13 patients reported adverse events, most often headache $(n=3)$ and skin lesions $(n=3)$. In four patients injection site reactions were present. The adverse events (AE) and/or the loss of the biosimilar efficacy were more commonly observed in women, patients with rheumatoid arthritis (especially in those who did not receive methotrexate), and in patients with a previous history of any other biological treatment. In patients in Group 2 the therapy was effective and no adverse events were observed. Conclusions: The etanercept biosimilar seems to be effective and well-tolerated in the majority of patients. Nevertheless, in some cases, switching from the originator to the biosimilar was associated with AEs or loss of efficacy.
\end{abstract}

Key words: inflammatory arthritis, biologics switching etanercept, biosimilar.

\section{Introduction}

Etanercept is a biological agent that inhibits proinflammatory cytokine - tumor necrosis factor (TNF). It is a human TNF receptor P75 Fc fusion protein produced by recombinant DNA technique using mammalian-based expression system: Chinese hamster ovary cells. Etanercept is indicated for the treatment of rheumatoid arthritis (RA), juvenile idiopathic arthritis (JIA), psoriatic arthritis (PSA), axial spondyloarthropathy (both ankylosing spondylitis - AS and axial spondyloarthropathy without radiological abnormalities), and plaque psoriasis [1]. At the time of this study, two etanercept products are available in Poland: the originator etanercept (ENB) and a biosimilar etanercept (SB4).

According to the European Medicines Agency (EMA) definition, a biosimilar is a medicine highly similar to another already marketed biological agent in terms of qualitative characteristics, biological activity, safety, and efficacy. In vitro studies of the biosimilar should verify its receptor binding potential and signal transduction at the target 
site of the originator. The second stage of drug evaluation involves in vivo studies in an animal model. The aim of clinical trials is to compare the pharmacokinetics, pharmacodynamics, efficacy, safety, and immunogenicity of both agents. If the novel compound was shown to be similar to the already marketed drug in one therapeutic indication, these data could be extrapolated to other indications without additional trials. However, some additional conditions need to be satisfied: the originator's mechanism of action, efficacy, and safety previously demonstrated should be the same regardless of the indication, and a post-marketing safety surveillance plan should be submitted by the biosimilar's manufacturer to the authorities [2].

The issue of replacing originators with their biosimilars has not been addressed in the EMA guidelines, leaving regulations in this area at the discretion of individual European Union member states [3]. The European Commission distinguishes between substitution, i.e. the practice of dispensing one medicine instead of an equivalent medicine at the pharmacy level without consulting the prescriber, and interchangeability, i.e. the practice of changing one medicine for another on the initiative or with the agreement of the prescriber. Moreover, the term switching exists, defined as the exchange of one medicine for another during treatment $[4,5]$. In Poland, no separate regulations exist for biosimilar agents, and distribution of these drugs follows the same rules as in the case of the generic agents, which means that the originator and the biosimilar can be freely replaced with one another $[5,6]$.

The etanercept biosimilar, with clinical trial code SB4, was approved by the EMA on January 14, 2016 [7]. Registration studies involving healthy volunteers and patients with RA confirmed the similarity of the etanercept originator and SB4 in terms of their pharmacokinetic characteristics, tolerance, and safety profiles. Furthermore, SB4 was shown to be less immunogenic than the originator $[8,9]$. In this paper, we present our experiences with the replacement of the etanercept originator with its biosimilar in patients with rheumatic diseases (RA, PsA, and ankylosing spondylitis) who received TNF inhibitors (TNFi) within the framework of drug programs.

\section{Material and methods}

The analysis included clinical data of patients treated with the etanercept biosimilar (50 mg weekly) within the framework of drug programs at the Biological Therapy Centre (BTC) of the National Institute of Geriatrics, Rheumatology and Rehabilitation in Warsaw (Poland). The study was conducted from November 2016 to May 2017. Because of the selection of the drug's provider based on the result of public bidding, permission from the Ethics Committee was not required.

Male and female patients fulfilling the following criteria were enrolled for treatment: RA meeting European League Against Rheumatism (EULAR) and American College of Rheumatology (ACR) classification criteria [10], AS diagnosed according to modified New York criteria with sacroiliitis in X-ray radiography [11], PsA meeting Classification for Psoriatic Arthritis (CASPAR) criteria [12] and high disease activity despite first-step treatment according to EULAR recommendations for RA [13], EULAR/ ASAS (Assessment of Spondyloarthritis International Society) for AS [14], and EULAR/ASAS/GRAPPA (Group for Research and Assessment of Psoriasis and Psoriatic Arthritis) for PsA [14-16]. In this study patients already treated with etanercept originator were eligible for enrolment as well as biologic-naïve patients.

All 168 analyzed patients characterized in Table I were enrolled into the study. In 162 cases the etanercept originator was replaced with its biosimilar (Group 1) regardless of the disease activity and duration of the orig-

Table I. Patient characteristics

\begin{tabular}{|c|c|c|}
\hline Characteristic & $\begin{array}{c}\text { Group 1 } \\
(n=162)\end{array}$ & $\begin{array}{c}\text { Group } 2 \\
(n=6)\end{array}$ \\
\hline Female, $n(\%)$ & $88(54.3)$ & $3(50)$ \\
\hline Age, mean \pm SD & $49.5 \pm 14.3$ & $41.5 \pm 11.6$ \\
\hline \multicolumn{3}{|l|}{ Diagnosis of inflammatory arthritis, $n(\%)$} \\
\hline Rheumatoid arthritis & $65(40.1)$ & $3(50)$ \\
\hline concomitant methotrexate therapy & $43(66.2)$ & $3(50)$ \\
\hline monotherapy & $22(33.8)$ & 0 \\
\hline Ankylosing spondylitis & $84(51.9)$ & $3(50)$ \\
\hline Psoriatic arthritis & $13(8)$ & 0 \\
\hline Etanercept as a first biologic agent, $n(\%)$ & $140(86.4)$ & $6(100)$ \\
\hline History of previous biologic therapy, $n$ (\%) & $22(13.6)$ & 0 \\
\hline
\end{tabular}


inator treatment. In six cases, due to high disease activity in biologic-naive patients, the biosimilar etanercept was implemented as the first biological agent (Group 2). Efficacy and safety of the treatment were monitored for six months after biosimilar treatment was initiated. Patients who were switched back to the originator were observed until recovery. Control visits were scheduled monthly. The RA, AS, and PsA were scored with the Disease Activity Score (DAS28), Bath Ankylosing Spondylitis Disease Activity Index (BASDAI), and Psoriatic Arthritis Response Criteria (PSARC), respectively [17-19].

The main focus of this study were reasons for biosimilar treatment discontinuation: loss of efficacy (LoE) or adverse events (AEs). Loss of efficacy was defined as aggravation in disease activity level or constantly high disease activity level measured with DAS28 for RA, upswing or constant BASDAI score > 4 for AS, and lack of response according to PSARC for PSA [17-19]. Subjective loss of efficacy (SLoE) was defined as aggravation of disease activity perceptible only by the patient without objective measurements. An adverse event was defined as a new health disorder that occurred during biosimilar treatment, confirmed by physical examination or medical history.

\section{Results}

In the vast majority of patients in Group $1(n=138$, $85.2 \%)$ the etanercept biosimilar was well tolerated, whereas in $24(14.8 \%)$ switching back to the originator was required due to the occurrence of AEs or LoE (duration of the originator treatment 3-90 months, mean 46.5 months). In nine patients (37.5\%), LoE was confirmed in a clinical scoring system specific to their primary condition. Six patients with RA showed an increase in DAS28 scores by 2.09-4.39 points (mean change 2.87, SD \pm 1.29 ). In two individuals with AS, BASDAI scores increased by 0.9 and 6.0, respectively (mean change 3.45, SD \pm 3.61 ). In one person with PsA, the activity of the disease remained at a high level. Another nine patients (37.5\%) reported subjective LoE and worsening of general health condition (back pain, arthralgia in previously non-painful joints, malaise, anxiety, fatigue). Moreover, 13 patients (54.2\%) reported AEs, most often headache $(n=3)$ and skin lesions ( $n=3$, itchy rash, exacerbation of skin psoriasis, or flare of pustular psoriasis). Other less frequent AEs, such as fatigue, anxiety, lower limb edema, elevated blood glucose (> $400 \mathrm{mg} / \mathrm{dl}$ ), increase in arterial blood pressure up to $195 / 90 \mathrm{~mm} \mathrm{Hg}$ in a patient with previously well controlled arterial hypertension, abdominal pain, vomiting, diarrhea, night sweats, and metallic taste in the mouth, were observed in single patients. In four patients (16.7\%) injection site reactions were present. In five patients, AEs co-existed with the LoE (assessed by physician), and in another two with a subjective lack of improvement (Table II). 23/24 patients showed a therapeutic response and/or resolution of AEs after switching back to the originator. In one person, switching back to the originator due to the lack of treatment effect of the biosimilar was associated with $A E$ in the form of a massive allergic skin reaction that required inpatient treatment in a dermatology unit. Eventually, this patient received another TNF inhibitor.

The AEs or LoE after switching from the etanercept originator to the biosimilar were more common in women than in men (75\%, 18/24 vs. 50.7\%, 70/138), and were more common in patients with RA than in other indications (50\%, 12/24 vs. 38.4\%, 53/138), among RA patients who did not receive methotrexate (MTX) (50\%, 6/12 vs. $30.2 \%, 16 / 53)$, and in patients with a previous history of biological treatment with other agents (25\%, 6/24 vs. $11.6 \%, 16 / 138)$.

In Group 2, for six patients who received etanercept biosimilar as the first biological agent, the therapy was effective, and no AEs were observed.

\section{Discussion}

According to literature, the proportion of patients in whom etanercept therapy had to be discontinued after switching from the originator to the biosimilar investigated in the presented study varies considerably [20-26]. In this study, we focused solely on persons in whom the etanercept biosimilar was withdrawn due to the occurrence of AEs or LoE. The patients who discontinued the treatment due to other reasons, such as remission, pregnancy, or elective surgery, were not included in the analysis.

The registration study of SB4 included adult patients with moderate to high activity of RA, who were

Table II. Causes of discontinuation of biosimilar in Group 1

\begin{tabular}{|lc|}
\hline Characteristic & Value \\
\hline All patients & $24 / 162(14.8)$ \\
\hline Loss of efficacy & $9 / 24(37.5)^{\star}$ \\
\hline Subjective lack of effect & $9 / 24(37.5)^{\star}$ \\
\hline Adverse effects & $13 / 24(54.2)^{\star}$ \\
\hline Headache & $3 / 24(12.5)$ \\
\hline Skin lesions & $3 / 24(12.5)$ \\
\hline Injection site reaction & $4 / 24(16.7)$ \\
\hline
\end{tabular}

* Numbers do not sum to $100 \%$ - in 5 patients adverse effects co-existed with the lack of objectively assessed treatment effect, and in another 2 with a subjective lack of improvement. 
Table III. Studies concerning the switch from etanercept originator to etanercept biosimilar

\begin{tabular}{|c|c|c|c|c|c|c|c|c|}
\hline Authors & $\begin{array}{l}\text { Emery } \\
\text { et al. } \\
{[20]}\end{array}$ & $\begin{array}{l}\text { Glintborg } \\
\text { et al. } \\
\text { [21] }\end{array}$ & $\begin{array}{l}\text { Hendricks } \\
\text { et al. } \\
\text { [22] }\end{array}$ & $\begin{array}{l}\text { De } \\
\text { Cock } \\
\text { et al. } \\
{[23]}\end{array}$ & $\begin{array}{l}\text { Holroyd } \\
\text { et al. } \\
\text { [24] }\end{array}$ & $\begin{array}{l}\text { Sigurdardottir } \\
\text { et al. } \\
\text { [25] }\end{array}$ & $\begin{array}{l}\text { Tweehuysen } \\
\text { et al. } \\
\text { [26] }\end{array}$ & $\begin{array}{l}\text { Felis-Giemza } \\
\text { et al. } \\
\text { (own study) }\end{array}$ \\
\hline $\begin{array}{l}\text { No. of patients switched } \\
\text { from etanercept orig- } \\
\text { inator to etanercept } \\
\text { biosimilar }\end{array}$ & 119 & 1548 & 85 & 29 & 110 & 147 & 636 & 162 \\
\hline Rheumatoid arthritis & $\begin{array}{c}119 \\
(100 \% \\
\text { concom- } \\
\text { itant } \\
\text { MTX })\end{array}$ & $\begin{array}{l}891 \\
(60 \% \text { con- } \\
\text { comitant } \\
\text { MTX) }\end{array}$ & No data & 29 & 58 & 76 & No data & $\begin{array}{c}65 \\
(66 \% \\
\text { concomitant } \\
\text { MTX) }\end{array}$ \\
\hline Psoriatic arthritis & 0 & $\begin{array}{l}335 \\
(49 \% \text { con- } \\
\text { comitant } \\
\text { MTX) }\end{array}$ & No data & 0 & 16 & 28 & No data & $\begin{array}{c}13 \\
(46 \% \\
\text { concomitant } \\
\text { MTX) }\end{array}$ \\
\hline Spondyloarthropathy & 0 & $\begin{array}{l}322 \\
(15 \% \text { con- } \\
\text { comitant } \\
\text { MTX) }\end{array}$ & No data & 0 & 15 & 25 & No data & $\begin{array}{c}84 \\
\text { (0 concom- } \\
\text { itant MTX) }\end{array}$ \\
\hline Other ${ }^{\star *}$ & 0 & 0 & No data & 0 & 4 & 18 & No data & 0 \\
\hline $\begin{array}{l}\text { Discontinuation due to } \\
\text { adverse effects or lack of } \\
\text { efficacy }\end{array}$ & $2(2 \%)$ & $101(7 \%)$ & $7(8 \%)$ & $\begin{array}{c}4 \\
(14 \%)\end{array}$ & 15 (14\%) & $12(8 \%)$ & $35(6 \%)$ & $24(15 \%)^{*}$ \\
\hline $\begin{array}{l}\text { Discontinuation due to } \\
\text { lack of efficacy }\end{array}$ & No data & $59(4 \%)$ & No data & $\begin{array}{l}\text { No } \\
\text { data }\end{array}$ & 14 (13\%) & $12(8 \%)$ & $19(3 \%)$ & $18(11 \%)^{\star}$ \\
\hline $\begin{array}{l}\text { Discontinuation due to } \\
\text { adverse effects }\end{array}$ & $2(2 \%)$ & $42(3 \%)$ & No data & $\begin{array}{l}\text { No } \\
\text { data }\end{array}$ & $1(1 \%)$ & 0 & $15(2 \%)$ & $13(8 \%)^{*}$ \\
\hline
\end{tabular}

* Numbers do not sum to $100 \%$ - in some patients adverse effects co-existed with the lack of objectively assessed treatment effect or subjective lack of improvement, ${ }^{* *}$ unclassified arthritis, enteropathic arthritis, juvenile idiopathic arthritis; MTX - methotrexate.

treated with MTX at a minimal dose of $10 \mathrm{mg}$ per week for at least six months before the randomization. Previous therapy with a biological agent was an exclusion criterion. The study patients were randomized into two groups, receiving SB4 or original drug for 52 weeks [9]. Then, patients from both groups were given SB4 up to week 100. Switching from the etanercept originator to the biosimilar compound was not associated with any clinically relevant events, such as an increase in $A E$ rate, higher immunogenicity, or LoE. The therapy was discontinued in only $2 \%$ of the patients, in all cases due to AEs [20].

The Danish observational study included patients with various profiles of rheumatic diseases, who switched from etanercept originator to SB4. Among them were patients treated with etanercept in monotherapy and previously treated with biologics. This was the largest analyzed group so far $(n=1548)$. The biosimilar compound was discontinued in $6.5 \%$ of the patients. In individuals with RA, the discontinuation of therapy turned out to be associated with the lack of concom- itant MTX treatment [21]. In another study, including a smaller group of Danish patients with an unknown profile of rheumatic diseases and MTX treatment, the etanercept biosimilar was withdrawn in $8 \%$ of the subjects. Six percent of patients who were switched back to the originator due to the lack of biosimilar's effect eventually achieved remission [22].

In a study conducted in the UK, including patients with RA, the described biosimilar was withdrawn in 14\% of the cases; the authors did not provide any information about MTX status in their patients. Three percent of patients were switched back to the originator, but no information about the outcome was provided [23]. In another British study of patients with various rheumatic diseases, therapy with an etanercept biosimilar was discontinued in $9 \%$ of the cases, primarily due to LoE; patients were switched back to the originator or with an unknown effect [24].

In a Swedish study, 8\% of patients discontinued the treatment with a biosimilar compound and were switched back to the originator, due to either objective 
(3\%) or subjective LoE (5\%). None of those patients showed a therapeutic response after switching back to the originator, and all of them required a change to another biological agent [25].

The aim of a Dutch study including a group of patients with various rheumatic diseases was to analyze the impact of different communication strategies on the acceptance of a biosimilar agent. The comparative analysis included patients who had been switched from infliximab originator to a biosimilar infliximab (CT-P13) and from etanercept originator to an etanercept biosimilar (SB4). Patients treated with etanercept were provided with more comprehensive information about the planned switch than were those receiving infliximab. Treatment discontinuation rates after switching to etanercept biosimilar and infliximab biosimilar were $6 \%$ and $24 \%$, respectively [26]. The authors of both studies mentioned above did not specify if any of their participants had a history of other biological therapies.

In all the studies mentioned above, etanercept biosimilar was discontinued in $8.4 \%$ of the patients on average $(2-14 \%)$, more often due to the LoE (in $7 \%$ of the cases on average) than because of AEs (in $2 \%$ on average). Compared with other studies, the extension study of etanercept biosimilar as SB4 had the lowest treatment discontinuation rate [20]. However, it should be emphasized that unlike clinical trials conducted in selected groups of patients, observational studies may include individuals with highly variable clinical profiles that occur in real-life practice [27]. This refers in particular to patients who had been previously treated with other biological agents, did not receive MTX, presented with coexisting diseases, or received the drug due to indications other than those covered by the regulatory trial (Table III). Moreover, it should be remembered that the causes of biosimilar therapy discontinuation among patients participating in previous studies differed substantially, from solely the presence of AEs in one to solely the LoE in another two.

Some studies documented the role of a nocebo effect in negative perception of biosimilar agents [28]. However, published data from independent centers suggest that switching to the etanercept biosimilar may be associated with the risk of AEs or LoE [21-26].

The emergence of biosimilar drugs is a natural consequence of the termination of patents on originator biologicals. Although biosimilars can be cheaper and thus accessible for more patients than the originators, the benefit-to-risk ratio is still a matter of debate. Furthermore, multiple switching due to non-medical causes cannot be excluded. In recent years EULAR and national experts, including Polish, have recommend the use of biosimilars in rheumatology [29, 30]. In 2017 Moorkens et al. [31] presented an article about policies for biosimilar uptake across European countries, which is particularly interesting from the point of view of drug policy, legal aspects, and therapy costs.

The need for an evaluation of multiple switching between originators and biosimilars and the patient's role in decision-making are emphasized. Biosimilars are approved as safe and efficacious agents. No additional trials are required for their use in indications other than those covered by the regulatory trial [29].

The presented study has some limitations, such as: a relatively small number of patients in Group 2 and the fact that some patients in Group 1 who reported a SLoE did not confirm this the disease activity scores. The potential possibility for a nocebo effect in Group 2 should also be considered. Contrarily, classification of some symptoms is very difficult - for example, malaise, fatigue, and anxiety could be AEs/SLoE; however, they could also be caused by an increase in disease activity. Furthermore, the disease activity at the moment of switching differed between patients, and the drug was switched regardless of the status of disease activity and duration of the originator treatment.

\section{Conclusions}

In our study, the etanercept biosimilar (SB4) turned out to be effective and well-tolerated in most patients, although in some of them the switching was associated with AEs or LoE, which eventually resulted in treatment discontinuation. In most of these cases, switching back to the originator resulted in control of the disease and the same switching tolerance as before the therapy. There is still a need for further investigation of results of switching between bio-originators and biosimilars. Also, in the situation of increasing access to novel biosimilars, switching between them requires further clinical observation and research.

The authors declare no conflict of interest.

\section{References}

1. Enbrel SmPC. Available from: http://www.ema.europa.eu/ docs/pl_PL/document_library/EPAR_-_Product_Information/ human/000262/WC500027361.pdf (accessed 26.01.2018).

2. European Medicines Agency: Guideline on similar biological medicinal products containing biotechnology-derived proteins as active substance: non-clinical and clinical issues. 18 December 2014, EMEA/CHMP/BMWP/42832/2005 Rev 1, Committee for Medicinal Products for Human Use (CHMP). Available from: http://www.ema.europa.eu/docs/en_GB/document_library/Scientific_guideline/2015/01/WC500180219. pdf (accessed 17.12.2017). 
3. European Medicines Agency: Similar biological medicinal products (overarching guideline). 23 October 2014, CHMP/437/04 Rev 1, Committee for Medicinal Products for Human Use (CHMP). Available from: http://www.ema.europa.eu/docs/ en_GB/document_library/Scientific_guideline/2014/10/ WC500176768.pdf (accessed 17.12.2017).

4. European Commission: What you need to know about biosimilar medicinal products. Ref. Ares(2014)4263293 18/12/2014. Available from: http://ec.europa.eu/DocsRoom/ documents/8242/attachments/1/translations/en/renditions/ pdf (accessed 2.01.2018).

5. Leki biologiczne w polskim systemie ochrony zdrowia. Raport demosEUROPA - Centrum Strategii Europejskiej. Warszawa, 2015. Available from: https://www.infarma.pl/assets/files/ innowacje/Leki_biologiczne_w_polskim_systemie_zdrowia_ Raport_demosEUROPA.pdf.

6. Komunikat Ministra Zdrowia MZ-PLA-460-15149-316/BRB/14 z dnia 14.04.2014. Available from: https://www.termedia.

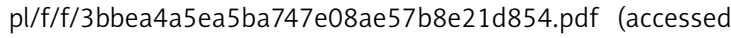
7.06.2017).

7. European Medicines Agency. Assessment report. Benepali. 19 November 2015, EMA/CHMP/819219/2015, Committee for Medicinal Products for Human Use (CHMP), Available from: http://www.ema.europa.eu/docs/en_GB/document_library/EPAR___Public_assessment_report/human/004007/ WC500200380.pdf (accessed 30.12.2017).

8. Lee YJ, Shin D, Kim Y, et al. A randomized phase I pharmacokinetic study comparing SB4 and etanercept reference product $\left(\right.$ Enbrel $\left.^{\oplus}\right)$ in healthy subjects. Br J Clin Pharmacol 2016; 82 64-73.

9. Emery P, Vencovský J, Sylwestrzak A, et al. A phase III randomised, double-blind, parallel-group study comparing SB4 with etanercept reference product in patients with active rheumatoid arthritis despite methotrexate therapy. Ann Rheum Dis 2017; 76: 51-57.

10. Aletaha D, Neogi T, Silman AJ, et al. 2010 Rheumatoid arthritis classification criteria: an American College of Rheumatology/ European League Against Rheumatism collaborative initiative. Ann Rheum Dis 2010; 69: 1580-1588.

11.van der Linden S, Valkenburg HA, Cats A. Evaluation of diagnostic criteria for ankylosing spondylitis. A proposal for modification of the New York criteria. Arthritis Rheum 1984; 27: 361-368.

12. Taylor W, Gladman D, Helliwell P, et al. Classification criteria for psoriatic arthritis: Development of new criteria from a large international study. Arthritis Rheum 2006; 54: 2665-2673.

13. Smolen JS, Landewé R, Bijlsma J, et al. EULAR recommendations for the management of rheumatoid arthritis with synthetic and biological disease-modifying antirheumatic drugs: 2016 update. Ann Rheum Dis 2017; 76: 960-977.

14.van der Heijde D, Ramiro S, Landewé R, et al. 2016 update of the ASAS-EULAR management recommendations for axial spondyloarthritis. Ann Rheum Dis 2017; 76: 978-991.

15. Gossec L, Smolen JS, Gaujoux-Viala C, et al. European League Against Rheumatism recommendations for the management of psoriatic arthritis with pharmacological therapies. Ann Rheum Dis 2012; 71: 4-12.
16. Coates LC, Kavanaugh A, Mease PJ, et al. Group for Research and Assessment of Psoriasis and Psoriatic Arthritis 2015 Treatment Recommendations for Psoriatic Arthritis. Arthritis Rheumatol 2016; 68: 1060-1071.

17. van Gestel AM, Prevoo ML, van 't Hof MA, et al. Development and validation of the European League Against Rheumatism response criteria for rheumatoid arthritis. Comparison with the preliminary American College of Rheumatology and the World Health Organization/International League Against Rheumatism Criteria. Arthritis Rheum 1996; 39: 34-40.

18. Garrett S, Jenkinson T, Kennedy LG, et al. A new approach to defining disease status in ankylosing spondylitis: the Bath Ankylosing Spondylitis Disease Activity Index. J Rheumatol 1994; 21: 2286-2291.

19. Clegg DO, Reda DJ, Mejias E, et al. Comparison of sulfasalazine and placebo in the treatment of psoriatic arthritis. A Department of Veterans Affairs Cooperative Study. Arthritis Rheum 1996; 39: 2013-2020.

20. Emery P, Vencovský J, Sylwestrzak A, et al. Long-term efficacy and safety in patients with rheumatoid arthritis continuing on SB4 or switching from reference etanercept to SB4. Ann Rheum Dis 2017; 76: 1986-1991.

21. Glintborg B, Sørensen I, Loft A, et al. FRI0190 Clinical outcomes from a nationwide non-medical switch from originator to biosimilar etanercept in patients with inflammatory arthritis after 5 months follow-up. Results from the danbio registry. Ann Rheum Dis 2017; 76: 553-554.

22. Hendricks O, Hørslev-Petersen K. When Etanercept Switch Fails - Clinical Considerations [abstract]. Arthritis Rheumatol 2017; 69 (Suppl 10). Available from: http://acrabstracts.org/ abstract/when-etanercept-switch-fails-clinical-considerations/ (accessed 14.01.2018).

23. De Cock D, Kearsley-Fleet L, Watson K, et al. Switching from RA Originator to Biosimilar in Routine Clinical Care: Early Data from the British Society for Rheumatology Biologics Register for Rheumatoid Arthritis [abstract]. Arthritis Rheumatol 2017; 69 (Suppl 10). Available from: http://acrabstracts.org/abstract/ switching-from-ra-originator-to-biosimilar-in-routine-clinical-care-early-data-from-the-british-society-for-rheumatologybiologics-register-for-rheumatoid-arthritis/ (accessed 14.01.2018).

24. Holroyd C, Wallis D, Bennett S, et al. Switching from bio-original etanercept to biosimilar etanercept SB4: Patient acceptability and outcomes in the real world. EULAR 2017; Abstract AB0377. Available from: http://scientific.sparx-ip.net/archiveeular/? view $=2 \&$ searchfor $=$ Switching $\% 20$ from $\% 20$ bio-original $\% 20$ etanercept\%20to\%20biosimilar\%20etanercept\%20SB4:\%20 Patient\%20acceptability\%20and\%20outcomes\%20in\%20the\%20real\%20world\&c=a\&item $=2017$ AB0377.

25. Sigurdardottir V, Husmark T, Svärd A. Switching from reference product etanercept to the biosimilar SB4 in a real-life setting: follow-up of 147 patients. Ann Rheum Dis 2017; 76: 835.

26. Tweehuysen L, Huiskes VJB, van den Bemt BJF, et al. Higher acceptance and persistence rates after biosimilar transitioning in patients with a rheumatic disease after employing an enhanced communication strategy. EULAR 2017; Abstract FRI0200. Available from: http://scientific.sparx-ip.net/archiveeular $/$ ?searchfor $=$ Higher $\% 20$ acceptance $\% 20$ and $\% 20$ 
persistence\%20rates\%20after\%20biosimilar\%20transitioning\%20in\%20patients\%20with\%20a\%20rheumatic\%20disease $\% 20$ after\%20employing\%20an\%20enhanced\%20communication\%20strategy\&c=a\&view=2\&item $=2017$ FRI0200.

27. Moots R, Azevedo V, Coindreau JL, et al. Switching between reference biologics and biosimilars for the treatment of rheumatology, gastroenterology, and dermatology inflammatory conditions: considerations for the clinician. Curr Rheumatol Rep 2017; 19: 37.

28. Tweehuysen L, van den Bemt BJF, van Ingen IL, et al. Subjective Complaints as the Main Reason for Biosimilar Discontinuation After Open-Label Transition From Reference Infliximab to Biosimilar Infliximab. Arthritis Rheumatol 2018; 70: 60-68.
29. Kay J, Schoels MM, Dörner T on behalf of the Task Force on the Use of Biosimilars to Treat Rheumatological Diseases, et al. Consensus-based recommendations for the use of biosimilars to treat rheumatological diseases. Ann Rheum Dis 2018; 77: 165-174.

30. Wiland P, Batko B, Brzosko M, et al. Biosimilar switching current state of knowledge. Reumatologia 2018; 56: 234-242. 31. Moorkens E, Vulto AG, Huys I, et al. Policies for biosimilar uptake in Europe: An overview. PLoS One 2017; 12: e0190147. 